\section{Soviets break the ice}

\section{Munich}

PERESIROIKA and concern over global warming may combine to give Western researchers access to the Arctic through one of the most inhospitable ocean routes in the world. Taking a cue from a speech by Mikhail Gorbachev at Murmansk in 1987, the Soviet government earlier this summer commissioned an international feasibility study to determine the economic and ecological consequences of the year-round opening of the ice-choked passage (see map) known as the Northern Sea Route. Researchers from three Western institutes met at Oslo in late June to begin the study, which they expect to complete by March next year.

Controversial studies of global warming done by Peter Wadhams, a University of Cambridge researcher, and others, indicate that the sea ice in the Arctic regions may be thinning (see Nature 345, 762 \& $795 ; 1990)$. Researchers are eager to obtain data concerning ice thickness, ice motion, and climate history, all of which might yield valuable clues about global warming, and it seems certain that access to the Soviet Arctic will increase.

"Soviet [polar] scientists have always been enthusiastic about cooperating with the West", says Wadhams. "Now it has become official government policy". Col-

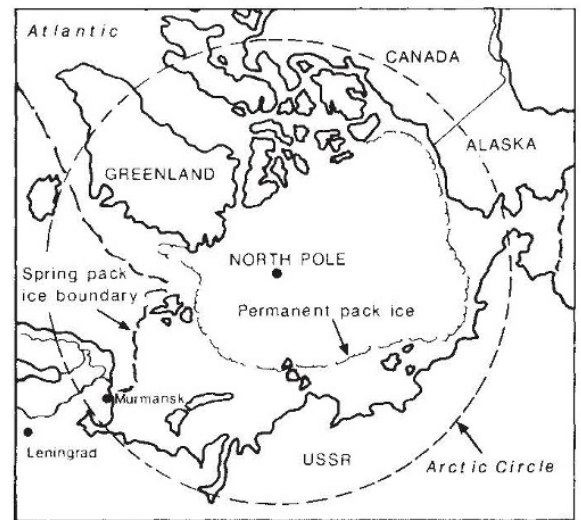

laborations were in the past always severely limited by Soviet security concerns, he adds.

As part of a joint West GermanNorwegian-European Communities project, Norway recently received permission to place in Soviet waters a sonar device that measures the thickness of sea ice, says Wadhams. More such devices might soon follow.

For the Soviet government, the Northern Sea Route is of considerable economic importance. During each summer, when icebreakers are used to clear a path, 1 to 4 million tonnes of cargo are shipped through the passage, which provides a short route from the Atlantic to the Pacific. The distance from Hamburg to Yokohama is reduced from about 12,000 nautical miles (through the Suez Canal) to less than 7,000 nautical miles and the journey time from 30 to 22 days.

The Soviets have built a large fleet of nuclear-powered and conventional ice breakers, says Arnfinn Jørgensen-Dahl of the Fridtjof Nansen Institute in Oslo, and by using them to keep the passage open all year round they could help their own economy and earn hard currency by charging foreign ships a fee for the journey.

But there is concern among Western researchers about the possible danger to the environment of the Soviet project.
"We assume there are dangers, especially from an oil spill", says Jørgensen-Dahl. Even though it could not stop the Soviet Union from opening the passage, the West can make a "positive contribution", he says, by ensuring that environmental damage is limited.

According to Wadhams, however, the dangers are "not negligible but not extremely serious". He does not expect oil tankers to use the passage. The environmental impact of opening the passage to international traffic, he says, would not be "any more severe" than the impact of current Soviet shipping.

Steven Dickman

\title{
Return of life unobserved
}

\section{Mount St Helens, Washington}

TEN years after the 50 -megaton volcanic eruption that scorched square miles of woodland into Mars-like desolation, Mount St Helens is coming back to life, largely unobserved. Most of the scientists who raced here in the summer of 1980 to record the first glimpses of life in this barren world are back at their universities, unable to get further funding for research at the volcano, and their minutely compiled data from the early years after the eruption now gather dust. But researchers say that, ten years on, Mount St Helens is perhaps more interesting than it was immediately after the explosion.

Its original ecosystem removed at a stroke, conditions at Mount St Helens approach laboratory purity. The species that first repopulated the blighted landscape in isolated pockets are now beginning to interact, giving a unique perspective on survival and evolutionary strategies. In the hot springs that flow from the crater itself are thermophilic bacteria that may resemble the first life on earth. And in the volcanic ash and mud, 200 metres deep in places, small patches of plant life constitute a textbook case of succession, one species paving the way for the next in a process that can take centuries elsewhere.

But as the attention of funding agencies has moved elsewhere, unique scientific opportunities at Mt St Helens are being lost. "It's a fleeting opportunity", says Robert Williams of the US Department of Agriculture. "Things aren't static, they won't be there for us next year". During the first four years after the explosion the recovery of $\mathrm{Mt} \mathrm{St}$ Helens was documented in detail, but those baseline studies have been abandoned and the continued biological evolution, now proceeding at exponential pace, is being recorded in only anecdotal fashion.

Research funding, which between 1980 and 1984 was over $\$ 1$ million a year, is now less than $\$ 100,000$ annually. More than
100 scientists studied the region in the early years, but now fewer than a dozen biologists make occasional trips - often with time and money borrowed from other research projects. Although 25 scientists from the US Geological Survey still monitor the volcano for seismic activity, research on accelerated erosion in the valley created by the vast 1980 mudslides is now better supported by the local logging company than by federal agencies.

Frustrated by the loss of a scientific opportunity at Mt St Helens, a group of biologists, geologists and ecologists earlier this year proposed a new "Mt St Helens Initiative", a $\$ 900,000$-a-year scientific return to the region. The scientists hope to get money for their project next year.

But going from concept to an actual appropriation will take some salesmanship. For the Mt St Helens scientists, that may be the biggest challenge of all. Unlike physicists and astronomers, who have been forced to master the ways of Washington to gain funding for their expensive projects, the initiative's supporters, like many "small science" researchers, appear to be badly out of touch with the politics of science.

At a day-long helicopter tour of the volcano for congressional staff and journalists last week, the researchers fumbled their chance to make a direct appeal. Abstractions like "interdisciplinary studies across the disturbance gradient", "infrastructure" and "synthesis" may be full of appeal to environmental researchers, but the congressional staff were clearly lost. Acknowledging a tactical error, the researchers privately said that they would attempt to draft a more lucid proposal and send it to selected members of Congress within weeks. Given the modest request, some increased support seems likely. But how much more could be won with a clever pitch may remain a hypothetical question.

Christopher Anderson 